\title{
Effect of Liquid Bioinoculants on Growth and Biomass of Coriander (Coriandrum sativum) and Methi (Trigonella foenum-graecum) under Greenhouse Conditions
}

\author{
H. Gurumurthy*, M.K. Shivaprakash, C.C. Maina and A.J. Shraddha \\ Department of Agricultural Microbiology, UAS, GKVK, Bengaluru-65, Karnataka, India \\ *Corresponding author
}

\section{A B S T R A C T}

\begin{tabular}{|l|}
\hline Ke y w o r d s \\
Liquid \\
biofertilizers, \\
Coriander and \\
Methi.
\end{tabular}

Keywords

Liquid

Coriander a Methi.

\section{Introduction}

The high cost of fertilizer production and environmental pollution caused by the use of chemical fertilizers makes necessary to use other sources especially biofertilizers which is a major aspect in organic farming. Today, biofertilizers have emerged as a highly potent alternative to chemical fertilizers due to their eco-friendly, easy to apply, non-toxic and cost effective in nature. They make nutrients that are naturally abundant in soil or atmosphere, usable for plants and act as supplements to agrochemicals. Liquid biofertilizer formulations are increasingly available in the market as one of the alternatives to chemical fertilizers and pesticides. One of the benefits from liquid biofertilizer is a contribution from population of microorganisms that are available.

Green leafy vegetables are the cheapest of all the vegetables within the reach of poor man, being richest in their nutritional value (Kuhnlein, 1996). Vegetables are highly beneficial for maintaining health and preventing diseases. Dark green leafy vegetables provide high amounts of microminerals which play vital roles in nutrient metabolism and retard degenerative diseases (Chu et al., 2002). Abbey et al., (2006) suggested the need to consume high vegetable meals to prevent colon and stomach cancers. Ball in 2006 reported high vitamin, dietary 
fiber and mineral contents of vegetables and the role they play in maintaining alkalinity in the body. Most green vegetables, are rich in magnesium, usually contain more than 500 $\mathrm{mg} / \mathrm{kg}$ fresh weight (WHO, 2004).

Coriander, commonly known as Dhania, originated from countries of Mediterranean Sea and is an integral part of Indian cuisine, seeds are regularly used as spice and leaves for garnishing curries, salads and soups. And it is a great source of potassium, iron, Vitamins A, K, and C, folic acid, magnesium, and calcium that can heal many health issues.

Methi is a leafy vegetable popular in both rural and urban areas and native to southern Europe and Asia. All parts of methi herb possess valuable medicinal properties and used both internally and as topical application in the treatment of many common diseases.

\section{Materials and Methods}

\section{Preparation of raised beds}

Land was cleared and fine tilth was given by using guddli and spade then make raised beds. Once the beds prepare different substrates were added like vermicompost and pongamia cake later mix with soil then allow it for stabilization.

\section{Preparation of liquid biofertilizers}

For this purpose, the respective broth was prepared and autoclaved at $121^{\circ} \mathrm{C}$ after autoclave cool it and inoculate the broth with respective mother culture then keep it for incubation. Media used for the preparation of liquid biofertilizers were Waksman. No.77 for Azatobacter, Sperbers media for PSB, Alexandrov's media for KSB, King's B broth for Pseudomonas flourescens, Nutrient broth for Bacillus subtilis and Potato dextrose broth for Trichoderma. The growth of microorganisms was observed by development of turbidity in the broth and the inoculums was diluted with water and applied to the raised beds before sowing.

\section{Observations recorded}

\section{Plant height}

Plant height was measured from the base of plant to the terminal growing point of the main stem at 7,21 and 30 DAS. The average plant height was expressed in centimetres.

\section{Number of leaves per plant}

The leaves which were fully opened and matured and were not senescent were counted for each plant and recorded as number of leaves per plant (5 plants/treatment) at 7, 21 DAS and 30 DAS.

\section{Shoot length $(\mathrm{cm})$}

Five normal plants were selected randomly from each treatment of all the replications at harvest. The shoot length was measured from collar region to the tip of the seedling with the help of a scale and the mean shoot length was expressed in centimeters.

\section{Root length (cm)}

Five normal randomly selected plants used for the measurement of root length. The root length measured from collar region to the tip of primary root with the help of a scale and the mean root length was expressed in centimeters.

\section{Root and shoot dry weight (g)}

The root and shoot of the same five seedlings selected for shoot and root length measurement were kept in butter paper bag and dried in an oven maintained at $85 \pm 2{ }^{\circ} \mathrm{C}$ 
for 24 hours. After drying, the butter paper bags were removed and kept in desiccators for cooling. The weight of shoot and root was recorded and mean dry weight of seedlings was calculated and was expressed in grams.

\section{Results and Discussion}

\section{Coriander}

The application of bioinoculants in different combinations on Coriander plants under greenhouse conditions at different days of sowing (DAS) have positive influence on plant height and number of leaves and the data pertaining to the effect of liquid bioinoculants is given in Table 1 .

\section{Plant height (cm)}

At $15 \mathrm{DAS}, \mathrm{T}_{5}$ which contained combination of different bioinoculants of Azotobacter chroococcum, Bacillus megaterium, Frateuria aurantia, Pseudomonas fluorescens, Bacillus subtilis and Trichoderma viridae recorded significantly higher plant height of $5.60 \mathrm{~cm}$ than $\mathrm{T}_{6}(5.27 \mathrm{~cm})$ which received Azotobacter chroococcum, Bacillus megaterium, Frateuria aurantia,, Trichoderma viridae and Bacillus subtilis, followed by $\mathrm{T}_{4}(4.97 \mathrm{~cm})$. Uninoculated control $\left(\mathrm{T}_{1}\right)$ recorded lowest plant height (3.23).

At 21 DAS, maximum plant height of Coriander was observed in the treatment $\mathrm{T}_{5}$ $(10.47 \mathrm{~cm})$ which received combination of different bioinoculatns like Azotobacter chroococcum, Bacillus megaterium, Frateuria aurantia, Pseudomonas fluorescens, Bacillus subtilis and Trichoderma viridae followed by $\mathrm{T}_{6}(10.20 \mathrm{~cm})$ which received Azotobacter chroococcum, Bacillus megaterium, Frateuria aurantiaand Pseudomonas fluorescens, and $\mathrm{T}_{4}(9.53 \mathrm{~cm})$ which received combinations of Azotobacter chroococcum, Bacillus megaterium, Frateuria aurantia and Trichoderma viridae.
At $30 \mathrm{DAS}, \mathrm{T}_{5}$ recorded significantly higher plant height of $21.47 \mathrm{~cm}$ than $\mathrm{T}_{6}$ and $\mathrm{T}_{4}$ which recorded $20.53 \mathrm{~cm}$ and $19.07 \mathrm{~cm}$ respectively. Uninoculated control $\left(\mathrm{T}_{1}\right)$ recorded lowest plant height $(14.53 \mathrm{~cm})$

\section{Number of leaves}

The bioinoculants have positive effect on number of leaves and at $15 \mathrm{DAS}, \mathrm{T}_{5}$ recorded maximum number of leaves (3.97) followed by $\mathrm{T}_{6}(3.80)$ and $\mathrm{T}_{7}$ (3.77). Lowest number of leaves (2.97) observed in uninoculated control $\left(\mathrm{T}_{1}\right)$.

At 21 DAS, maximum number of leaves (6.97) recorded in $\mathrm{T}_{5}$ (Azotobacter chroococcum, Bacillus megaterium, Frateuria aurantia, Pseudomonas fluorescens, Bacillus subtilis and Trichoderma viridae), followed by $\mathrm{T}_{6}(6.53)$ and at par with each other.

Other treatments, $\mathrm{T}_{7}, \mathrm{~T}_{4}, \mathrm{~T}_{3}$ and $\mathrm{T}_{8}$ recorded $6.47,6.43,6.40$ and 6.37 respectively and at par with each other. Uninoculated control $\left(\mathrm{T}_{1}\right)$ recorded lowest number of leaves (5.77).

At 30 DAS, $T_{5}$ recorded significantly higher number of leaves (11.07) than $\mathrm{T}_{6}$ and $\mathrm{T}_{7}$ which recorded 10.03 and 10.00 respectively and at par with each other.

Treatments $T_{4}, T_{3}$ and $T_{8}$ recorded number of leaves of 9.97, 9.80 and 9.77 respectively and at par with each other. $\mathrm{T}_{1}$ which was not treated with any bioinoculants recorded lowest number of leaves (8.63).

\section{Root length (cm)}

The highest root length $(5.80 \mathrm{~cm})$ was recorded in the treatment $T_{5}$ followed by $T_{6}$ $(4.50 \mathrm{~cm})$. Other treatments $\mathrm{T}_{7}, \mathrm{~T}_{4}$ and $\mathrm{T}_{8}$ recorded root length of $4.30 \mathrm{~cm}, 4.20 \mathrm{~cm}$ and $4.17 \mathrm{~cm}$ respectively and at par with each other. The lowest root length was recorded in the uninoculated control $(2.90 \mathrm{~cm})$. 


\section{Shoot length $(\mathrm{cm})$}

The observation regarding shoot length was recorded and the maximum shoot length $(21.47 \mathrm{~cm})$ was observed in $\mathrm{T}_{5}$ followed by $\mathrm{T}_{6}$ $(20.53 \mathrm{~cm})$. The significantly lowest shoot length was recorded in the untreated control $(14.53 \mathrm{~cm})$.

\section{Root and Shoot fresh weight (g)}

The maximum root and shoot fresh weight $(5.87 \mathrm{~g})$ was recorded in the treatment $\mathrm{T}_{5}$ followed by $\mathrm{T}_{6}(5.17 \mathrm{~g})$ compared to other treatments. The significantly lowest shoot fresh weight was recorded in the untreated control $(2.77 \mathrm{~g})$.

\section{Root and shoot dry weight (g)}

The treatment $T_{5}$ recorded significantly higher root and shoot dry weight $(2.37 \mathrm{~g})$ followed by $\mathrm{T}_{7}(1.80 \mathrm{~g})$ and $\mathrm{T}_{6}(1.77 \mathrm{~g})$ and at par with each other. The lowest dry weight of the root was recorded in the untreated control $(0.63 \mathrm{~g})$. The increasing growth parameters and biomass is because the synergistic effect of both PGPR and biocontrol agents.

However, plants receiving all six liquid bio inoculants recorded maximum growth parameters when compared to un-inoculated plants with nutrients. This data reveals that the effect of microbial inocula alone is comparable to that of addition of fertilizers.

The PGPRs and biocontrol agents might have increased nutrient availability in the soils which in turn helped better proliferation of root and shoot growth, chlorophyll content and uptake of other nutrients to a greater extent. These results are in agreement with Nanthakumar and Veeraraghavathatham (2003) in brinjal.

\section{Methi}

The effect of liquid bioinoculants on growth of Methi in raised beds under greenhouse condition have positive influence and the data regarding plant height and number of leaves are given in Table 2.

\section{Treatment details}

\begin{tabular}{|c|c|}
\hline $\mathrm{T}_{1}$ & Control \\
\hline $\mathrm{T}_{2}$ & A. $\operatorname{chroococcum~}($ A.c) + B. megaterium $($ B.m $)+F$. aurantia $($ F.a $)$ \\
\hline $\mathrm{T}_{3}$ & A. chroococcum $($ A.c) + B. megaterium $($ B.m $)+F$. aurantia $($ F.a $)+B . s u b t i l i s ~(B . s)$ \\
\hline $\mathrm{T}_{4}$ & A. chroococcum $($ A.c) + B. megaterium $($ B.m $)+F$. aurantia $($ F.a $)+$ T.viridae $($ T.v $)$ \\
\hline $\mathrm{T}_{5}$ & $\begin{array}{l}\text { A. chroococcum }(\text { A.c })+B . \text { megaterium }(\text { B.m })+F . \text { aurantia }(\text { F.a })+\text { T.viridae }(\text { T.v })+P . \\
\text { fluorescens }(\text { P.f })+\text { B.subtilis }(\text { B.s })\end{array}$ \\
\hline $\mathrm{T}_{6}$ & A. $\operatorname{chroococcum}($ A.c) + B. megaterium $($ B.m $)+F$. aurantia $($ F.a) $+P$. fluorescens $($ P.f) \\
\hline $\mathrm{T}_{7}$ & A. chroococcum (A.c) + B. megaterium (B.m) + T.viridae $($ T.v) + B.subtilis $($ B.s $)$ \\
\hline $\mathrm{T}_{8}$ & A. chroococcum (A.c) + B. megaterium (B.m) + P. fluorescens $(\mathrm{P} . \mathrm{f})+$ T.viridae $(\mathrm{T} . \mathrm{v})$ \\
\hline
\end{tabular}


Table.1 Effect of liquid bioinoculants on growth and biomass of Coriender in raised beds under greenhouse condition

\begin{tabular}{|c|c|c|c|c|c|c|c|c|c|c|}
\hline \multirow{2}{*}{ Treatments } & \multicolumn{3}{|c|}{ Plant height $(\mathbf{c m})$} & \multicolumn{3}{|c|}{ Number of leaves } & \multirow{2}{*}{$\begin{array}{l}\text { Root length } \\
(\mathrm{cm})\end{array}$} & \multirow{2}{*}{$\begin{array}{c}\text { Shoot length } \\
\text { (cm) }\end{array}$} & \multirow{2}{*}{$\begin{array}{l}\text { Root and Shoot } \\
\text { Fresh weight (g) }\end{array}$} & \multirow{2}{*}{$\begin{array}{l}\text { Root and Shoot } \\
\text { Dry weight (g) }\end{array}$} \\
\hline & 15 DAS & 21DAS & 30 DAS & 15 DAS & 21DAS & 30 DAS & & & & \\
\hline $\mathrm{T}_{1}$ & $3.23^{\mathrm{f}}$ & $7.67^{\mathrm{d}}$ & $14.53^{\mathrm{f}}$ & $2.97^{\mathrm{c}}$ & $5.77^{\mathrm{b}}$ & $8.63^{\mathrm{c}}$ & $2.90^{\mathrm{e}}$ & $14.53^{\mathrm{f}}$ & $2.77^{\mathrm{e}}$ & $0.63^{\mathrm{e}}$ \\
\hline $\mathrm{T}_{2}$ & $3.63^{\mathrm{e}}$ & $8.70^{c}$ & $15.93^{\mathrm{e}}$ & $3.50^{\mathrm{b}}$ & $6.17^{\mathrm{ab}}$ & $9.47^{b}$ & $3.77^{\mathrm{d}}$ & $15.93^{\mathrm{e}}$ & $3.77^{\mathrm{d}}$ & $1.13^{\mathrm{d}}$ \\
\hline $\mathrm{T}_{3}$ & $3.80^{\mathrm{de}}$ & $8.83^{c}$ & $16.20^{\mathrm{e}}$ & $3.60^{\mathrm{ab}}$ & $6.40^{\mathrm{ab}}$ & $9.80^{b}$ & $4.10^{\mathrm{cd}}$ & $16.20^{\mathrm{e}}$ & $3.80^{\mathrm{d}}$ & $1.20^{\mathrm{d}}$ \\
\hline $\mathrm{T}_{4}$ & $4.97^{b}$ & $9.53^{\mathrm{bc}}$ & $19.07^{\mathrm{c}}$ & $3.73^{\mathrm{ab}}$ & $6.43^{\mathrm{ab}}$ & $9.97^{b}$ & $4.20^{\mathrm{bc}}$ & $19.07^{\mathrm{c}}$ & $4.70^{c}$ & $1.57^{\mathrm{c}}$ \\
\hline $\mathrm{T}_{5}$ & $5.60^{\mathrm{a}}$ & $10.47^{\mathrm{a}}$ & $21.47^{\mathrm{a}}$ & $3.97^{\mathrm{a}}$ & $6.97^{\mathrm{a}}$ & $11.07^{\mathrm{a}}$ & $5.80^{\mathrm{a}}$ & $21.47^{\mathrm{a}}$ & $5.87^{\mathrm{a}}$ & $2.37^{\mathrm{a}}$ \\
\hline $\mathrm{T}_{6}$ & $5.27^{b}$ & $10.20^{\mathrm{ab}}$ & $20.53^{b}$ & $3.80^{\mathrm{ab}}$ & $6.53^{\mathrm{ab}}$ & $10.03^{b}$ & $4.50^{b}$ & $20.53^{b}$ & $5.17^{b}$ & $1.77^{\mathrm{bc}}$ \\
\hline $\mathrm{T}_{7}$ & $4.20^{c}$ & $9.23^{c}$ & $17.23^{\mathrm{d}}$ & $3.77^{\mathrm{ab}}$ & $6.47^{\mathrm{ab}}$ & $10.00^{b}$ & $4.30^{b c}$ & $17.23^{\mathrm{d}}$ & $4.87^{b c}$ & $1.80^{\mathrm{bc}}$ \\
\hline $\mathrm{T}_{8}$ & $4.00^{\mathrm{cd}}$ & $9.17^{\mathrm{c}}$ & $16.47^{\mathrm{e}}$ & $3.63^{\mathrm{ab}}$ & $6.37^{\mathrm{ab}}$ & $9.77^{b}$ & $4.17^{\mathrm{bc}}$ & $16.47^{\mathrm{e}}$ & $4.60^{\mathrm{c}}$ & $2.03^{b}$ \\
\hline SEM \pm & 0.08 & 0.19 & 0.18 & 0.08 & 0.20 & 0.13 & 0.09 & 0.18 & 0.10 & 0.06 \\
\hline
\end{tabular}

Note: $\mathrm{T}_{1}$ - Control, $\mathrm{T}_{2}$ - A. chroococcum (A.c) + B. megaterium (B.m) $+F$. aurantia $(\mathrm{F} . \mathrm{a}), \mathrm{T}_{3}$ - A. chroococcum $($ A.c) + B. megaterium $($ B.m $)+F$. aurantia $(\mathrm{F} . \mathrm{a})+$ B.subtilis (B.s), $\mathrm{T}_{4-}$ A. chroococcum (A.c) + B. megaterium (B.m) + F. aurantia (F.a) + T.viridae (T.v), $\mathrm{T}_{5^{-}}$A. chroococcum (A.c) + B. megaterium $($B.m $)+F$. aurantia $\left(\right.$ F.a) + T.viridae $($ T.v $)+$ P. fluorescens $\left(\right.$ P.f) + B.subtilis (B.s), $\mathrm{T}_{6}-$ A. chroococcum $($ A.c $)+$ B. megaterium (B.m) $+F$. aurantia $($ F.a $)+P$. fluorescens (P.f), $\mathrm{T}_{7}$ - A. chroococcum (A.c) + B. megaterium (B.m) + T.viridae (T.v) +B.subtilis (B.s) and $\mathrm{T}_{8}$ : A. chroococcum (A.c) + B. megaterium (B.m) + P. fluorescens (P.f) + T.viridae (T.v)

Table.2 Effect of liquid bioinoculants on growth and biomass of Methi in raised beds under greenhouse condition

\begin{tabular}{|c|c|c|c|c|c|c|c|c|c|c|}
\hline \multirow{2}{*}{ Treatments } & \multicolumn{3}{|c|}{ Plant height $(\mathrm{cm})$} & \multicolumn{3}{|c|}{ Number of leaves } & \multirow{2}{*}{$\begin{array}{l}\text { Root length } \\
(\mathrm{cm})\end{array}$} & \multirow{2}{*}{$\begin{array}{c}\text { Shoot length } \\
\text { (cm) }\end{array}$} & \multirow{2}{*}{$\begin{array}{l}\text { Root and Shoot } \\
\text { Fresh weight (g) }\end{array}$} & \multirow{2}{*}{$\begin{array}{l}\text { Root and Shoo } \\
\text { Dry weight (g) }\end{array}$} \\
\hline & 15 DAS & 21DAS & 30 DAS & 15 DAS & 21DAS & 30 DAS & & & & \\
\hline $\mathrm{T}_{1}$ & $5.80^{\mathrm{g}}$ & $13.60^{\mathrm{e}}$ & $25.50^{f}$ & $5.10^{\mathrm{e}}$ & $10.87^{\mathrm{d}}$ & $20.60^{\mathrm{e}}$ & $4.17^{\mathrm{d}}$ & $25.50^{\mathrm{f}}$ & $1.12^{\mathrm{e}}$ & $0.48^{\mathrm{f}}$ \\
\hline $\mathrm{T}_{2}$ & $6.67^{\mathrm{ef}}$ & $13.87^{\mathrm{d}}$ & $30.23^{\mathrm{e}}$ & $5.60^{\mathrm{d}}$ & $11.40^{\mathrm{c}}$ & $23.33^{\mathrm{d}}$ & $4.70^{\mathrm{c}}$ & $30.23^{\mathrm{e}}$ & $1.85^{\mathrm{d}}$ & $0.67^{\mathrm{ef}}$ \\
\hline $\mathrm{T}_{3}$ & $6.85^{\mathrm{de}}$ & $15.00^{\mathrm{d}}$ & $31.33^{\mathrm{d}}$ & $6.00^{\mathrm{cd}}$ & $11.60^{\mathrm{c}}$ & $23.60^{\mathrm{d}}$ & $4.77^{\mathrm{c}}$ & $31.33^{\mathrm{d}}$ & $2.31^{\mathrm{c}}$ & $0.83^{\text {cde }}$ \\
\hline $\mathrm{T}_{4}$ & $7.01^{\mathrm{d}}$ & $16.10^{\mathrm{c}}$ & $31.53^{\mathrm{d}}$ & $6.20^{\mathrm{bc}}$ & $12.10^{\mathrm{b}}$ & $25.90^{\mathrm{c}}$ & $5.10^{\mathrm{bc}}$ & $31.53^{\mathrm{d}}$ & $2.63^{b c}$ & $0.90^{\mathrm{cd}}$ \\
\hline $\mathrm{T}_{5}$ & $8.95^{\mathrm{a}}$ & $18.70^{\mathrm{a}}$ & $38.13^{\mathrm{a}}$ & $6.93^{\mathrm{a}}$ & $14.53^{\mathrm{a}}$ & $29.40^{\mathrm{a}}$ & $6.00^{\mathrm{a}}$ & $38.13^{\mathrm{a}}$ & $3.24^{\mathrm{a}}$ & $1.43^{\mathrm{a}}$ \\
\hline $\mathrm{T}_{6}$ & $7.99^{b}$ & $17.17^{b}$ & $36.20^{\mathrm{b}}$ & $6.60^{\mathrm{ab}}$ & $12.40^{\mathrm{b}}$ & $27.20^{b}$ & $5.80^{\mathrm{a}}$ & $36.20^{b}$ & $3.17^{\mathrm{a}}$ & $1.13^{b}$ \\
\hline $\mathrm{T}_{7}$ & $7.41^{\mathrm{c}}$ & $16.90^{b}$ & $32.30^{\mathrm{c}}$ & $6.40^{b c}$ & $12.17^{b}$ & $26.87^{b}$ & $5.33^{b}$ & $32.30^{\mathrm{c}}$ & $2.88^{\mathrm{ab}}$ & $1.03^{b c}$ \\
\hline $\mathrm{T}_{8}$ & $6.50^{f}$ & $15.73^{\mathrm{c}}$ & $31.40^{\mathrm{d}}$ & $6.13^{\mathrm{c}}$ & $11.70^{\mathrm{c}}$ & $25.40^{\mathrm{c}}$ & $4.80^{\mathrm{c}}$ & $31.40^{\mathrm{d}}$ & $2.27^{\mathrm{c}}$ & $0.70^{\mathrm{de}}$ \\
\hline SEM \pm & 0.08 & 0.14 & 0.11 & 0.10 & 0.09 & 0.12 & 0.10 & 0.11 & 0.09 & 0.05 \\
\hline
\end{tabular}

Note: $\mathrm{T}_{1}$ - Control, $\mathrm{T}_{2}-$ A. chroococcum (A.c) + B. megaterium (B.m) $+F$. aurantia $(\mathrm{F} . \mathrm{a}), \mathrm{T}_{3}-$ A. chroococcum $($ A.c $)+B$. megaterium $(\mathrm{B} . \mathrm{m})+F$. aurantia $(\mathrm{F} . \mathrm{a})+$ B.subtilis (B.s), $\mathrm{T}_{4}$ - A. chroococcum (A.c) + B. megaterium (B.m) + F. aurantia (F.a) + T.viridae (T.v), $\mathrm{T}_{5^{-}}$A. chroococcum (A.c) + B. megaterium (B.m) $+F$.

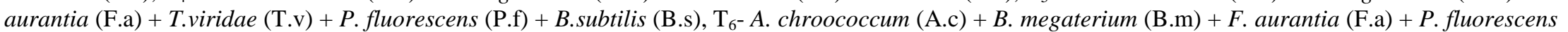
(P.f), $\mathrm{T}_{7}$ - A. chroococcum (A.c) + B. megaterium (B.m) + T.viridae (T.v) + B.subtilis (B.s) and $\mathrm{T}_{8}$ : A. chroococcum (A.c) + B. megaterium (B.m) + P. fluorescens (P.f) + T.viridae (T.v) 


\section{Plant height (cm)}

At 15 DAS, $\mathrm{T}_{5}$ (Azotobacter chroococcum, Bacillus megaterium, Frateuria aurantia, Pseudomonas fluorescens, Bacillus subtilis and Trichoderma viridae) recorded significantly highest plant height $(8.95 \mathrm{~cm})$ compared to $\mathrm{T}_{6}$ $(7.99 \mathrm{~cm})$. Lowest plant height was recorded in uninoculated control $(5.80 \mathrm{~cm})$.

At $21 \mathrm{DAS}, \mathrm{T}_{5}$ recorded maximum plant height $(18.70 \mathrm{~cm})$ followed by $\mathrm{T}_{6}(17.17 \mathrm{~cm})$ and $\mathrm{T}_{7}$ $(16.90 \mathrm{~cm})$ and at par with each other. $\mathrm{T}_{1}$ (uninoculated control) recorded lowest plant height $(13.60 \mathrm{~cm})$.

At 30 DAS, maximum plant height $(38.13 \mathrm{~cm})$ was recorded in $\mathrm{T}_{5}$ followed by $\mathrm{T}_{6}(36.20 \mathrm{~cm})$. Lowest plant height $(25.50 \mathrm{~cm})$ was recorded in uninoculated control $\left(\mathrm{T}_{1}\right)$.

\section{Number of leaves}

The liquid bioinoculants have positive influence on number of leaves and at 15 DAS, $T_{5}$ recorded maximum number of leaves (6.93) followed by $T_{6}(6.60)$ and $T_{7}(6.40)$. Lowest number of leaves (5.10) was observed in uninoculated control $\left(\mathrm{T}_{1}\right)$.

At 21 DAS, maximum number of leaves (14.53) was recorded with $\mathrm{T}_{5}$ (Azotobacter chroococcum, Bacillus megaterium, Frateuria aurantia, Pseudomonas fluorescens, Bacillus subtilis and Trichoderma viridae), followed by $\mathrm{T}_{6}$ (12.40) and $\mathrm{T}_{7}$ (12.17) and $\mathrm{T}_{6}$ and $\mathrm{T}_{7}$ are at par with each other. Uninoculated control $\left(\mathrm{T}_{1}\right)$ recorded lowest number of leaves (10.87)

Observations were recorded at 30 DAS. $T_{5}$ recorded significantly higher number of leaves (29.40) than $T_{6}$ and $T_{7}$ which recorded 27.20 and 26.87 respectively. $\mathrm{T}_{6}$ and $\mathrm{T}_{7}$ are at par with each other. Treatments $\mathrm{T}_{4}$, and $\mathrm{T}_{8}$ recorded number of leaves of 25.90 and 25.40 respectively and at par with each other. $\mathrm{T}_{1}$ which was not been treated with any bioinoculants recorded lowest number of leaves (8.63).

\section{Root length (cm)}

Maximum root length $(6.00 \mathrm{~cm})$ was recorded in the treatment $\mathrm{T}_{5}$ followed by $\mathrm{T}_{6}(5.80 \mathrm{~cm})$ and at par with each other. Lowest root length $(4.17 \mathrm{~cm})$ was recorded in the uninoculated control $\left(\mathrm{T}_{1}\right)$.

\section{Shoot length (cm)}

Maximum shoot length $(38.13 \mathrm{~cm})$ was recorded in the $\mathrm{T}_{5}$ followed by $\mathrm{T}_{6}(36.20 \mathrm{~cm})$. The significantly lowest shoot length $(25.50$ $\mathrm{cm})$ was recorded in the untreated control $\left(\mathrm{T}_{1}\right)$.

\section{Root and shoot fresh weight (g)}

The maximum root and shoot fresh weight (3.24 g) was recorded in the treatment $T_{5}$ followed by $\mathrm{T}_{6}$ (3.17 g) and at par with each other. The significantly lowest shoot dry weight was recorded in the untreated control (1.12 g).

\section{Root and shoot dry weight (g)}

Maximum root and shoot dry weight $(1.43 \mathrm{~g})$ was recorded in $\mathrm{T}_{5}$ followed by $\mathrm{T}_{7}(1.13 \mathrm{~g})$ and $\mathrm{T}_{6}(1.03 \mathrm{~g})$. Uninocaulated control $\left(\mathrm{T}_{1}\right)$ recorded lowest root and shoot dry weight $(0.48 \mathrm{~g})$.

Increased plant growth may be attributed to sufficient nutrient mobilization to plant growth due to effective functioning of introduced microbial inoculants. The bio-active substances produced by these microorganisms might have helped in better nutrient uptake for the plant growth. These results are in conformity with the findings of many research workers who reported such increased plant height due to biofertilizers application in various crops like, onion (Ragland et al.,1989; Nagraju et al., 2001), coriander (Subramanian and Vijaykumar, 2000).

The maximum fresh weight of plants was significantly influenced by application of microbial inoculants. Maximum fresh weight was recorded in the treatment with 75 per cent $\mathrm{N}$, $\mathrm{P}$ plus full dose of $\mathrm{K}$ with $A$. brasilense, $B$. 
megaterium inoculation. The lowest fresh weight per plant was recorded in the plots treated with recommended FYM alone. These results are in similarity with the findings of Sreeramulu et al., (1996) in amaranthus and methi, wherein they recorded more fresh weight due to application of microbial inoculants. These results are in conformity with the findings of Nirmala and Vadivel (1999) in cucumber, where in they made triple inoculation of A. brasilense, B. megaterium and Glomus fasciculatum. Similar increase in plant dry weight due to microbial inoculation was also reported in onion (Ragland et al., 1989), tomato (Mohandas, 1987) and in brinjal (Kandaswamy et al., 1985).

\section{References}

Abbey, L., Bonsu, K. O., Glover, A. M. and Ahenkora, K., 2006. Evaluation of some common leafy vegetables used in Ghana Crop Research Institute, Kumasi. Ghana Journal of Horticulture, 5: 23.

Ball, G. F. M., 2006. Vitamins in Foods. Analysis, bioavailability and stability. CRC Taylor \& Francis, Boca-Raton.

Chu, Y. F., SUN, J., Wu, X., Liu, R. H., 2002. Antioxidant and anti-proliferative activities of common vegetables. Rev. J. Agric. Food Chem., 50: 6910-6916.

Kandaswamy, D., Mohanraj Samuel, G. and Oblisami, G., 1985. Influence of VAMycorrhizae and phosphobacteria on growth of brinjal and chillies in nursery. South Indian Hort., 33(3): 172-176.

Kuhnlein, H. V., and Receveur, O., 1996. Dietary change and traditional food systems of indigenous peoples. Annual Review of Nutrition, 16: 417- 442.

Mohandas, S., 1987. Field response of tomato
(Lycopersicon esculentum Mill.) cv. Pusa Ruby to inoculation with VAmycorrhizae fungus (Glomus fasciculatum and Azotobacter vinelandii), Plant Soil, 98(2): 295-297.

Nagaraju, R., Haripriya, K. and Purushotham, K., 2001, Influence of VA-mycorrhizal inoculation under varying phosphorus levels and sources on onion. South Indian Hort., 49: 204-207.

Nanthakumar, S., Veeraragavathatham.D. 2003. Role of integrated nutrient management on the nutrient content of plant tissues in brinjal (Solanum melongena L.) cv. PLR.1. South Indian Hort 51(6): 163-167.

Nirmala, R., and Vadivel, E., 1999. Effect of combined application of organic manure and bio-fertilizers on growth and productivity of cucumber. South Indian Hort., 47(1-6): 252-254.

Ragland, J. G. S., Thamburaj and Kandasamy, 1989. Studies on the effect of biofertilizers on the bulb yield in Bellary onion (Allium cepa L.). South Indian Hort., 37(3): 150-152.

Sreeramulu, K. R., Vishwanath Shetty, Y. and Prabhakara Setty, T. K., 1996. Effect of VA Mycorrhiza on the growth of two important leafy vegetables. Madras Agric. J., 83 (6): 362-364

Subramanian, S. and Vijaykumar, M., 2000. Effect of various level of nitrogen and Azospirillum on growth and yield of coriander (Coriandrum sativum L.). South Indian Hort., 40: 191-194.

World Health Organization, 2004. Vitamin and mineral requirements in human nutrition (Second edition). Food and Agricultural Organization of the United Nations, 11: 217-229.

\section{How to cite this article:}

Gurumurthy, H., M.K. Shivaprakash, C.C. Maina and Shraddha, A.J. 2017. Effect of Liquid Bioinoculants on Growth and Biomass of Coriander (Coriandrum sativum) and Methi (Trigonella foenum-graecum) under Greenhouse Conditions. Int.J.Curr.Microbiol.App.Sci. 6(10): 891-897. doi: https://doi.org/10.20546/ijcmas.2017.610.107 